\title{
Pengaruh Metode Group Investigation Materi Gaya terhadap Sikap Ilmiah Peserta Didik di MI Al-Huda Karangnongko Yogyakarta
}

\author{
Mizaniya \\ UIN Sunan Kalijaga Yogyakarta \\ Jl. Laksda Adisucipto, Papringan, Caturtunggal, Sleman, Yogyakarta 55281 \\ email: 19204080018@student.uin-suka.ac.id \\ Moh. Agung Rokhimawan \\ UIN Sunan Kalijaga Yogyakarta \\ Jl. Laksda Adisucipto, Papringan, Caturtunggal, Sleman, Yogyakarta 55281 \\ email: rokhimawan78@gmail.com
}

Received: Feb 8, 2020

Revised: April 17, 2020

Accepted: May 24, 2020

\begin{abstract}
Thistudy was aimed to examine the difference in the average value of scientific attitudes in the experimental class using the group investigation method and the control class using conventional learning methods before being treated as well as after being treated and see the influence of the Group Investigation on the scientific attitude of students at MI Al-Huda Karangnongko Yogyakarta. This was a quasi-experimental (quasi-experimental) study involving 56 students. The sample of this study was class IV A as an experimental class and class IV B as a control class. This sample was taken using a random class sampling technique. Data collection used guidelines and observation sheets. The data analysis technique used mann whiney (non-parametric) for scale results after treatment. Statistical data shows there is an increase in the average scientific attitude of the experimental class before using the group investigation method by 19.5 and after using the group investigation method by 23.4. This has increased the method by 3.9. In the control class, the average scientific attitude also experienced an increase from scale scale data before treatment 17.2 and after treatment 23.03. Then the increase in the average value of control control was 5.83. Descriptive statistical results shows the scale before the treatment of mann whiney analysis (non-parametric) shows the Significance value of Sig. (2 tailed) = $0.487>0.05$, then $\mathrm{Ha}$ is rejected and Ho is accepted. This means that there is no significant difference between the average value before and after the scientific attitude. Then it can be concluded that there is no difference in the scientific attitude of students in class IV MI Al-Huda Karangnongko Yogyakarta.
\end{abstract}

Keywords: Style, Group Investigation, Scientific Attitude 


\begin{abstract}
Abstrak
Tujuan penelitian ini untuk mengetahui perbedaan nilai rata-rata sikap ilmiah pada kelas eksperimen menggunakan metode group investigation dan kelas kontrol dengan menggunakan metode pembelajaran konvensional sebelum diberi perlakuan serta serta setelah diberi perlakuan. Serta melihat pengaruh Group Investigation terhadap sikap ilmiah peserta didik di MI Al-Huda Karangnongko Yogyakarta. Variabel yang diukur adalah sikap ilmiah pada peserta diidk kelas IV di MI Al-Huda Karangnongko Yogyakarta. Penelitian ini menggunakan eksperimen semu (quasi eksperimen). Populasi dari penelitian ini adalah seluruh siswa kelas IV di MI Al-Huda Karangnongko Yogyakarta yang berjumlah 56 orang peserta didik yang terdiri dari 2 kelas. Sampel penelitian ini ialah kelas IV A sebagai kelas eksperimen dan kelas IV B sebagai kelas kontrol. Sampel ini diambil menggunakan teknik random class sampling. Pengumpulan data dengan menggunakan pedoman dan lembar observasi. Teknik analisis data menggunakan mann whiney (non-parametrik) untuk hasil skala setelah perlakuan. Data statistik menunjukan terdapat peningkatan rata-rata sikap ilmiah kelas eksperimen sebelum menggunakan metode group investigation sebesar 19,5 serta setelah menggunakan metode group investigation sebesar 23,4. Hal tersebut mengalami peningkatan metode sebesar 3,9. Pada kelas kontrol rata-rata sikap ilmiah juga mengalami peningkatan dari data skala skala sebelum perlakuan 157,2 dan setelah perlakuan 23,03. Maka peningkatan nilai rata-rata pada keals kontrol sebesar 5,83. Hasil statistik deskriptif dengan bantuan SPSS 16.00 terlihat skala sebelum perlakuan analisis mann whiney (non-parametrik) menunjukkan nilai Signifikansi Sig. (2 tailed) =0,487>0,05, maka $\mathrm{H}_{a}$ ditolak dan $\mathrm{H}_{\mathrm{o}}$ diterima. Hal ini berarti tidak terdapat perbedaan yang signifikan antara nilai rata-rata sebelum dan sesudah sikap ilmiah. Maka dapat disimpulkan bahwa tidak terdapat perbedaan terhadap sikap ilmiah pada peserta didik kelas IV MI Al-Huda Karangnongko Yogyakarta.
\end{abstract}

Kata Kunci: Gaya, Group Investigation, Sikap Ilmiah

\section{Pendahuluan}

Pendidikan merupakan wadah untuk berlatih, berkreasi, mewujudkan cita-cita manusia yang berkualitas disamping itu juga melatih ketrampilan di dalam bidang tertentu. Perubahan kualitas pembelajaran merupakan salah satu dasar peningkatan pendidikan keseluruhan. Pendidikan di sekolah tidak bisa lepas dari kegiatan belajar mengajar, yang meliputi seluruh aktivitas yang menyangkut yang menyangkut pemberian materi pelajaran agar siswa memperoleh kecakapan pengetahuan yang bermanfaat bagi kehidupan. Ilmu Pengetahuan Alam (IPA) merupakan mata pelajaran yang menekankan adanya proses ilmiah.

Pembelajaran proses sains dalam konteks kurikulum 2013 dilakukan berdasarkan pada pendekatan ilmiah yang menuntut siswa berpikir secara sistematis dan kritis dalam upaya memecahkan suatu masalah. Dengan sikap ilmiah yang tertanam dan berkembang dalam diri siswa, siswa diharapkan mampu bersikap peka terhadap lingkungan, mampu mencari tahu apa yang mereka temukan, apa yang mereka belum mereka ketahui dan siswa diharapkan mampu bertindak dan menyelesaikan masalah yang ada di lingkunganya dengan kemampuan dirinya sendiri. Sikap ilmiah dapat mempengaruhi prestasi belajar baik pada aspek kognitif, afektif, maupun psikomotorik. Sikap ilmiah merupakan kecenderungan orang atau individu untuk bertindak atau berperilaku dalam memecahkan suatu masalah secara sistematis melalui langkah-langkah ilmiah. Dalam aspek sikap ilmiah, siswa dibelajarkan untuk membandingkan fakta yang ditemui terhadap dampak yang mungkin terjadi terhadap hasil belajar. Pembelajaran group investigation sangat cocok untuk pelajaran sains yang bertujuan untuk melibatkan peserta didik dalam penyelidikan ilmiah serta mendorong peserta didik untuk berkontribusi pada pembelajaran di dalam kelas. Melalui kerjasama kelompok 
dan penyelidikan, metode group investigation mendorong peserta didik dapat memperoleh suatu penemuan.

Berdasarkan uraian di atas, maka peneliti bermaksud untuk mengadakan penelitian tentang "Pengaruh Metode Group Investigation Materi Gaya Terhadap Sikap Ilmiah Peserta Didik di MI Al-Huda Karangnongko Yogyakarta". Permasalahan dalam penelitian ini dapat dirumuskan sebagai berikut apakah terdapat perbedaan rata-rata sikap ilmiah sebelum diberi perlakuan dan setelah diberi perlakuan pada kelas eksperimen dan kelas kontrol. Tujuan dari penelitian ini ialah untuk mengetahui perbedaan rata-rata sikap ilmiah sebelum diberi perlakuan dan setelah diberi perlakuan pada kelas eksperimen dan kelas kontrol. Manfaat dari penelitian ini ialah memotivasi untuk menerapkan metode pembelajaran yang lebih bervariasi sehingga materi pembelajaran akan lebih menarik.

Group Investigation ialah penemuan yang dilaksanakan secara berkelompok, dimana mengalami serta melakukan percobaan dengan aktif yang memungkinkannya menemukan prinsip. ${ }^{1} \quad$ Metode pembelajaran Group Investigation adalah salah satu tipe model pembelajaran kooperatif dimana metode pembelajaran ini menekankan pada interaksi individu dalam suatu kelompok untuk saling bekerjasama sehingga tujuan pembelajaran dapat tercapai dengan baik. Metode pembelajaran Group Investigation terdapat tiga konsep utama yakni penelitian atau inquiri, pengetahuan atau knowledge, serta dinamika kelompok atau the dynamic of the learning group. ${ }^{2}$ Langkah-langkah metode pembelajaran Group Investigation (Investigasi Grup) yaitu seleksi topik, merencanakan kerjasama, implementasi, analisis \& sintesis, penyajian hasil akhir, serta

${ }^{1}$ Robert E Slavin, Cooperative Learning (Bandung: Nusa Media, 2008), 216.

${ }^{2}$ Udin S. Winaputra, Model Pembelajaran Inovatif (Jakarta: Universitas Terbuka, 2011), 75. evaluasi. $^{3}$ Kelebihan metode pembelajaran Group Investigation (Investigasi Grup) adalah memberi semangat untuk berinisiatif, kreatif, aktif serta dapat belajar untuk memecahkan dan menangani suatu masalah. ${ }^{4}$

Sikap ilmiah disebut juga sikap sains atau keilmuan. Sikap ilmiah berarti sikap yang dimiliki para ilmuwan dalam mencari dan mengambangkan pengetahuan baru, misalnya sikap objektif terhadap fakta-fakta, hati-hati, bertanggung jawab, berhati terbuka, selalu ingin meneliti, dan lain-lain. ${ }^{5}$ Sikap ilmiah peserta didik dapat berupa ketertarikan terhadap suatu masalah, kemampuan menyampaikan pendapat serta menghargai pendapat orang lain, kemmapuan untuk menyelesaikan masalah, serta bekerja sama dengan orang lain. Sikap ilmiah tersebut haruslah dimiliki peserta didik, karena dapat membantu proses belajar. Hal ini dikarenakan sikap ilmiah pada peserta didik dapat membentuk cara berpikir logis kritis, dan sistematis. Sikap ilmiah bisa dikatakan sebagai karakter yang menjadi persyaratan para ilmuwan dalam mencari kebenaran ilmiah. ${ }^{6}$ Sikap ilmiah ialah salah satu bentuk kecerdasan yang dimiliki oleh peserta didik dalam pembelajaran. Sikap ilmiah peserta didik dalam pembelajaran dapat mempengaruhi hasil belajar peserta didik. Sikap ilmiah peserta didik pada dasarnya berbeda dengan keterampilan-keterampilan lain (kognitif, sosial, proses, dan psikomotor). Dapat disimpulkan bahwa sikap ilmiah adalah suatu perbuatan yang bersifat ilmiah yang didasarkan pada pendirian atau keyakinan.

Anak-anak dalam rentang usia 7 11 tahun baru mampu berpikir sistematis

${ }^{3}$ Yasin. B Nurhadi and Senduk A.G, Pembelajaran Kontekstual (Contextual Teaching and Learning/ CTL) Dan Penerapaannya Dalam KBK (Malang: Universitas Negeri Malang, 2004), 66.

${ }^{4}$ Aris Shoimin, 68 Model Pembelajaran Inovatif Dalam Kurikulum 2013 (Rembang: Ar-Ruzz Media, 2014), 80.

${ }^{5}$ Patta Bundu, Penilaian Keterampilan Proses Dan Sikap Ilmiah Dalam Pembelajaran Sains SD (Jakarta: Departemen Pendidikan Nasional, 2006), 137.

${ }^{6}$ Herabudin, Ilmu Alamiah Dasar (Bandung: Pustaka Setia, 2013), 67. 
mengenai benda-benda dan persitiwaperistiwa yang konkret.7 Sehingga dengan kemampuan peserta didik sekolah dasar maka sikap ilmiah yang perlu dikembangkan dan tumbuh dijiwa anak ialah kemampuan untuk menghargai orang lain dan keberanian peserta didik untuk menjawab pertanyaan, mengajukan pertanyaan, dan berdiskusi. ${ }^{8}$ American Association for Advancement of Science memberikan penekanan pada empat sikap yang perlu untuk ditingkatkan pada sekolah dasar yakni honesty (kejujuran), curiosity (keingintahuan), open minded (keterbukaan), dan skepticism (ketidakpercayaan). ${ }^{9}$ Sembilan aspek sikap dari ilmiah yang dapat dikembangkan pada anak SD/MI, yaitu: ${ }^{10}$ Sikap ingin tahu, sikap ingin mendapatkan sesuatu yang baru, sikap kerja sama, sikap tidak putus asa, sikap tidak berprasangka, sikap mawas diri, sikap bertanggung jawab, sikap berpikir bebas, serta sikap kedisiplinan diri.

pengukuran sikap ilmiah dapat dilakukan melalui beberapa indikator sikap yang dikembangkan berdasarkan setiap dimensi untuk memudahkan dalam menyususn instrumen. ${ }^{11}$ Indikator setiap dimensi, sebagai berikut: ${ }^{12}$ 1) Sikap ingin tahu meliputi antusias mencari jawaban, perhatian pada objek yang diamati, antusias terhadap proses sains, \& menanyakan setiap langkah kegiatan, 2) Sikap senantiasa mendahulukan data atau fakta meliputi objektif atau jujur, tidak memanipulasi data, tidak berprasangka, mengambil keputusan sesuai fakta, \& tidak mencampur fakta dengan pendapat, 3) Sikap berpikir kritis meliputi meragukan temuan

7 Muhibbin Syah, Psikologi Pendidikan Dengan Pendekatan Baru (Bandung: Remaja Rosdakarya, 2014), 70-72.

${ }^{8}$ Usman Samatowa, Bagaimana Membelajaran IPA Di Sekolah Dasar (Jakarta: Depdiknas, 2006), 87.

9 Bundu, Penilaian Keterampilan Proses Dan Sikap Ilmiah Dalam Pembelajaran Sains SD, 40.

10 Hendro Darmodjo, Pendidikan IPA II (Jakarta: Depdiknas, 1991), 7.

${ }^{11}$ Darmodjo, 32.

12 Bundu, Penilaian Keterampilan Proses Dan Sikap Ilmiah Dalam Pembelajaran Sains SD, 141. teman, menanyakan setiap perubahan atau hal yang baru, mengulangi kegiatan yang dilakukan, \& tidak mengabaikan data meskipun kecil, 4) Sikap penemuan dan kreativitas meliputi menggunakan fakta-fakta untuk dasar konklusi, menunjukkan laporan berbeda dengan teman sekelas, merubah pendapat dalam merespon terhadap fakta, menggunakan alat tidak seperti biasanya, menyarankan percobaan-percobaan baru, \& menguraikan konklusi baru hasil pengamatan, 5) Sikap berpikiran terbuka dan kerja sama meliputi menghargai pendapat / temuan orang lain, mengubah pendapat jika data kurang, menerima saran teman, tidak merasa paling benar, menganggap setiap kesimpulan adalah tentatif, \& berpartisipasi aktif dalam kelompok, 6) Sikap ketekunan meliputi melanjutkan meneliti sesudah "kebaruan" hilang, \& mengulangi percobaan meskipun teman sekelasnya selesai lebih awal, 5) Sikap peka terhadap lingkungan sekitar meliputi perhatian terhadap peristiwa sekitar, partisipasi pada kegiatan sosial, \& menjaga kebersihan lingkungan sekolah.

Kegiatan yang agak bebas tetapi terkendali akan memberikan peluang yang baik untuk mengembangkan sikap ilmiah. Meletakkan barang baru dan tidak lazim dalam kelas akan mendorong rasa ingin tahu. Mendiskusikan pengamatan yang dilakukan saat kegiatan berlangsung ataupun sesudahnya akan memunculkan sikap kritis. ${ }^{13}$ Sikap ilmiah diukur dengan bentuk penilaian non test. Teknik penilaian non test yang sering digunakan ialah pengamatan (observasi), melakukan wawancara, menyebarkan angket (kuisioner), dan dokumen (dokumentasi). ${ }^{14}$ Penelitian yang dilakukan menggunakan teknik penilaian pengamatan (observasi). Pengamatan ialah cara mengumpulkan data dengan mengadakan pencatatan terhadap apa yang menjadi sasaran pengamatan. Guru

\footnotetext{
${ }^{13}$ Bundu, 46.

14 Bundu, 142.
} 
dapat melakukan penilaian sikap ilmiah pada waktu peserta didik melakukan pengamatan. Pengamatan sebagai lat evaluasi disamping digunakan sebagai untuk menilai sikap dan tingkah laku peserta didik juga digunakan dalam menilai keterampilan peserta didik melakukan praktikum atau percobaan. ${ }^{15}$

Penelitian ini mengambil materi pada tema 8 daerah tempat tinggalku 8. Pada subtema 2 keunikan daerah tempat tinggalku terhadap pembelajaran 1 dan pembelajaran 2 . Pembelajaran 1 memuat mata pelajaran Bahasa Indonesia dan Ilmu Pengetahuan Alam (IPA) serta pembelajaran 2 memuat mata pelajaran SBdP dan Ilmu Pengetahuan Alam (IPA).

\section{Metode Penelitian}

Jenis penelitian yang digunakan yaitu penelitian kuantitatif. Metode penelitian ini yaitu Quasi Experimental Design. Penelitian ini menggunakan Quasi Experimental Design berjenis Nonequivalent Control Group Design dengn rumus, sebagai berikut: ${ }^{16}$

Tabel 1.1 Desain Penelitian

\begin{tabular}{cccc}
\hline Kelas & $\begin{array}{c}\text { Skala } \\
\text { (Sebelum } \\
\text { Perlakuan) }\end{array}$ & Perlakuan & $\begin{array}{c}\text { Skala } \\
\text { (Setelah } \\
\text { Perlakuan) }\end{array}$ \\
\hline Eksperimen & $\mathrm{O}_{1}$ & $\mathrm{X}_{1}$ & $\mathrm{O}_{2}$ \\
\hline Kontrol & $\mathrm{O}_{3}$ & - & $\mathrm{O}_{4}$ \\
\hline
\end{tabular}

Keterangan:

$\mathrm{X}=$ Perlakuan menggunakan metode group investigation

$\mathrm{O}_{1}-\mathrm{O}_{3}=$ Kondisi yang belum diberi perlakuan $\mathrm{O}_{2}-\mathrm{O}_{4}=$ Kondisi setelah diberi perlakuan

Variabel dalam penelitian ini yaitu variabel terikat dimana variabel terikat ini adalah sikap ilmiah peserta didik kelas IV dan variabel bebas dimana variabel bebas ini adalah penerapan metode pemeblajaran group investigation pada kelas atau kelompok eksperimen kelas IV. Penelitian ini populasinya yaitu seluruh seluruh peserta didik MI Al-

15 Bundu, 142 .

16 Sugiyono, Metode Penelitian Kuantitatif, Kualitatif, Dan R E D (Bandung: Alfabeta, 2016), 77-79.
Huda Karangnongko Yogyakarta Tahun Ajaran 2018/2019. Pengambian sampel dengan cara teknik random class sampling. Sampel penelitian ini ialah kelas IV A sebagai kelas eksperimen dan kelas IV B sebagai kelas kontrol. Jumlah sampel dalam penelitian ini dijelaskan pada tabel 1.2 dibawah ini sebagai berikut:

Tabel 1.2 Sampel Penelitian di MI Al-Huda Karangnongko Yogyakarta

\begin{tabular}{ccccc}
\hline No & Kelas & $\begin{array}{c}\text { Laki- } \\
\text { Laki }\end{array}$ & Perempuan & Jumlah \\
\hline 1. & $\begin{array}{c}\text { IV A } \\
\text { (Eksperimen) }\end{array}$ & $\begin{array}{c}\text { Peserta } \\
\text { Didik }\end{array}$ & $\begin{array}{c}\text { 14 Peserta } \\
\text { Didik }\end{array}$ & $\begin{array}{c}28 \\
\text { Peserta } \\
\text { Didik }\end{array}$ \\
\hline 2. & IV B & $\begin{array}{c}15 \\
\text { (Kontrol) } \\
\text { Deserta } \\
\text { Didik }\end{array}$ & $\begin{array}{c}\text { 13 Peserta } \\
\text { Didik }\end{array}$ & $\begin{array}{c}\text { Peserta } \\
\text { Didik }\end{array}$ \\
\hline & Jumlah & $\begin{array}{c}29 \\
\text { Keseluruhan } \\
\text { Peserta } \\
\text { Didik }\end{array}$ & $\begin{array}{c}\text { 27 Peserta } \\
\text { Didik }\end{array}$ & $\begin{array}{c}\text { Peserta } \\
\text { Didik }\end{array}$ \\
\hline
\end{tabular}

Teknik dan instrumen penelitian ini ialah pedoman observasi. Teknis analisis data pada penelitian ini yaitu Pertama, uji prasyarat analisis meliputi uji normalitas dan uji homogenitas dimana kedua uji ini menggunakan dengan bantuan software SPSS 16.00 yakni menggunakan uji KolmogorovSmirnov dan Shapiro-Wilk. Kedua, uji hipotesis dimana analisis dalam penelitian ini menggunakan bantuan software SPSS 16.00 yakni menggunakan uji Mann-Whitney.

\section{Hasil dan Pembahasan}

Berdasarkan penelitian yang telah dilakukan, maka dibawah ini penjabaan hasil dan pembahan yang dilakukan oleh penliti, sebagai berikut:

Hasil pengujian uji normalitas dapat ditunjukkan pada tabel 1.3 di bawah ini:

Tabel 1.3 Hasil Uji Normalitas Skala Sebelum Perlakuan

Tests of Normality

\begin{tabular}{ccccccc}
\hline \multirow{2}{*}{ Kelompok } & \multicolumn{3}{c}{ Kolmogorov- $^{\text {Smirnov }}$} & \multicolumn{3}{c}{ Shapiro-Wilk } \\
\cline { 2 - 7 } & Statistic & df & Sig. & Statistic & df & Sig. \\
\hline Nilai Kelas &, 257 & 26 &, 000 &, 815 & 26 &, 000 \\
Eksprerimen & & 26 &, 068 &, 950 & 26 &, 230 \\
Kelas Kontrol &, 165 & 26 & & & & \\
\hline
\end{tabular}

a. Lilliefors Significance Correction 
Dari hasil uji normalitas pada tabel 1.3 diperoleh kesimpulan bahwa sampel tidak berdistribusi normal. Karena nilai signifikansi dari skala sebelum perlakuan kelas eksperimen (IV A) melalui uji kolmogorov-smirnov sebesar 0,000 dan uji shapiro-wilk sebesar 0,000 lebih kecil dari 0,05 sedangkan nilai signifikansi skala sebelum perlakuan kelas kontrol (IV B) melalui uji kolmogorov-smirnov sebesar 0,068 dan uji shapiro-wilk sebesar 0,230 lebih besar dari 0,05 .

Hasil pengujian homogenitas variansi dapat ditunjukkan pada tabel 1.4 di bawah ini:

\begin{tabular}{lcccc} 
Tabel 1.4 Hasil Uji Homogenitas Skala Sebelum & $\begin{array}{c}\text { Perlakuan } \\
\text { Tests of Homogenitas of Variance }\end{array}$ \\
\hline & $\begin{array}{l}\text { Levene } \\
\text { Statistic }\end{array}$ & d1 & df2 & Sig. \\
\hline $\begin{array}{l}\text { NilaiBased on } \\
\text { Mean }\end{array}$ & 4,864 & 1 & 50 &, 032 \\
\hline $\begin{array}{l}\text { Based on Median } \\
\text { Based on Median } \\
\text { and with adjusted } \\
\text { df }\end{array}$ & 1,579 & 1 & 50 &, 215 \\
\hline $\begin{array}{l}\text { Based on trimmed } \\
\text { mean }\end{array}$ & 4,820 & 1 & 50 &, 033 \\
\hline
\end{tabular}

Dari tabel 1.4 dapat dilihat bahwa nilai signifikansi sebesar 0,032. Jika nilai signifikansi lebih kecil dari 0,05 $(0,032<0,05)$ maka sampel yang diambil dari populasi berasal dari variansi yang tidak sama atau tidak homogen.

Berdasarkan uji prasyarat analisis di atas yaitu uji normalitas dan uji homogenitas yang telah dilakukan, memberikan informasi bahwa data dalam penelitian ini tidak memiliki sebaran data normal dan memiliki sebaran data tidak homogen karena semua data yang diuji ada data yang tidak berdistribusi normal dan ada yang berdistribusi tidak homogen. Sehingga pengujian hipotesis dengan menggunakan statistik parametrik tidak dapat dilakukan. Sebagai alternatif maka uji hipotesis dilakukan non parametrik yaitu dengan uji Mann Whitney.
Hasil pengujian Mann Whitney dapat ditujukkan pada tabel di bawah ini:

Tabel 1.5 Hasil Uji Mann Whitney

Ranks

\begin{tabular}{lcccc}
\hline \multicolumn{1}{c}{ Kelas } & & N & $\begin{array}{c}\text { Mean } \\
\text { Rank }\end{array}$ & $\begin{array}{c}\text { Sum of } \\
\text { Ranks }\end{array}$ \\
\hline $\begin{array}{l}\text { Sikap ilmiah } \\
\text { eksperimen }\end{array}$ & kelas & 28 & 29,63 & 800,00 \\
kontrol & kelas & 28 & 26,43 & 740,00 \\
& & 56 & & \\
\hline & Total & & & \\
\hline
\end{tabular}

\begin{tabular}{lc}
\multicolumn{2}{c}{ Test Statistic $^{3}$} \\
\hline Mann-Whitney U & Sikap ilmiah \\
Wilcoxon W & 334,000 \\
Z & 740,000 \\
Asymp. Sig. (2-tailed) &,- 754 \\
\hline
\end{tabular}

a. Grouping Variabel: kelas

Berdasarkan uji tabel 1.5 , diperoleh Asymp. Sig. (2-tailed) bernilai sebesar 0,487. Karena nilai 0,487 lebih besar dari 0,05 maka dapat disimpulkan bahwa " $\mathrm{H}_{\mathrm{a}}$ ditolak dan $\mathrm{H}_{0}$ diterima" Artinya tidak terdapat perbedaan yang signifikan antara rata-rata sikap ilmiah kelas eksperimendan rata-rata sikap ilmiah kelas kontrol. Maka dapat disimpulkan bahwa tidak terdapat pengaruh metode group investigation terhadap sikap ilmiah peserta didik kelas IV A.

Sebelum diberikan perlakuan dengan menggunakan metode group investigation sikap ilmiah pada kelas eksperimen sudah terlihat. Namun hanya beberapa saja misalnya sikap ingin tahu dibuktikan dengan peserta didik yang selalu aktif bertanya jika terdapat persoalan dengan seksama. Selain itu peserta didik juga sudah berpartisipasi aktif dalam kelompok, terbukti saat berdiskusi mereka saling memberi masukan dan mengerjakan bersaama.Selanjutnya, peneliti akan melihat apakah sikap ilmiah yang lain sudah berkembang. untuk itu peneliti mengambil tiga sikap yang diobservasi melalui perlakuan menggunakan metode pembelajaran group 
investigation yaitu sikap ingin tahu. Sikap senantiasa mendahulukan fakta, dan sikap, dan sikap berpikir terbuka dan bekerja sama.

Sikap ilmiah yang diambil oleh peneliti masing-masing hanya ada dua indikator sebagai penilaian. Jadi, jumlah keseluruhan indikator yang dinilai dan dianalisis oleh peneliti yaitu enam. Hal ini agar tidak terlalu banyak indikator yang diamati oleh peneliti. Serta agar indikator yang diambil dipandang muncul pada peserta didik saat proses pembelajaran.

Berdasarkan data penelitian pada kelas eksperimen diperoleh hasil skala perlakuan rata-ratasikap ilmiah yaitu sebesar 19,5 dan skala setelah perlakuan rata-rata sikap ilmiah menjadi 23,4. Berdasarkan hasil tersebut bahwa rata-rata sikap ilmiah pada kelas rata-rata sikap ilmiah pada kelas eksperimen mengalami kenaikan sebesar 3,9. Sedangkan kelas kontrol rata-rata sikap ilmiah mengalami peningkatan dari data skala sebelum perlakuan sebesar 17,2 dan skala setelah perlakuan menjadi sebesar 23,03. Maka peningkatan nilai rata-rata pada kelas kontrol sebesar 5,83.

Peningkatan rata-rata sikap ilmiah kelas eksperimen lebih sedikit dibandingkan kelas kontrol. Hal ini disebabkan karena saat pengambilan data sebelum perlakuan peserta didik lebih bisa dikondisikan oleh guru, dan melakukan percobaan dengan teliti. Dimana peserta didik tidak keluyura, selalu aktif bertanya, dan menyampaikan pendapat. Berbeda saat pengambilan data saat perlakuan, bahkan terdapat beberapa peserta didik yang keluyuran, bermain dengan alat peraga, keluar masuk kelas, ada beberaap peserta didik yang tidak mau membacakan diskusinya di depan kelas, terkadang di dalam kelompok hanya beberapa orang saja yang mengerjakan tugas dan ramai sendiri. Walaupun sebagain peserta didik ada yang berdiskusi dan melakukan percobaan dengan langkah-langkah yang dijelaskan.

Namun, pada kelas kontrol mengalami peningkatan kenaikan rata-rata sikap ilmiah lebih besar. Hal ini dikarenakan saat pengambilan data skala sebelum perlakuan peserta didik hanya melakukan kegiatan pembelajaran beberapa menit saja. Dikarenakan guru yang mengampu sedang ada pertemuan. Sehingga peserta didik hanya diberi tugas untuk dikerjakan. Dan peneliti diminta untuk menjaga di kelas. Sedangkan pada saat pengambilan skala setelah perlauan, peserta didik berdiskusi dengan tertib, peserta didik terlihat lebih aktif, tidak sungkan untuk bertanya dan menyampaikan jawabannya, bahkan peserta didik lebih teliti, karena bisa mengoreksi jawaban guru yang salah. Tidak terdapat peserta didik yang bermain sendiri, dan tidak ada peserta didik keluar masuk kelas.

Berdasarkan data tersebut maka dapat disimpulkan bahwa metode group investigation dapat meningkatkan nilai rata-rata pada kelas eksperimen. Tetapi metode konvensional juga dapat meningkatkan nilai rata-rata pada kelas kontrol. Dari hasi rata-rata tersebut masih perlu pembuktian untuk melihat pengaruh metode group investigation berpengaruh atau tidak terhadap sikap ilmiah. Maka perlu dilakuakn uji hipotesis menggunakan Mann Whitney.

Berdasarkan hasil hipotesis menggunakan analisis Mann Whitney, maka diperoleh nilai Asymp. Sig. (2 tailed) $=0,487>0,05, \mathrm{Maka} \mathrm{H}_{\mathrm{a}}$ ditolak dan $\mathrm{H}_{0}$ diterima. Hal ini berarti bahwa tidak terdapat perbedaan yang signifikan antara niali rata-rata kelas eksperimen dengan nilai rata-rata kelas kontrol. Maka dapat disimpulkan bahwa tidak terdapat pengaruh metode group investigation terhadap sikap ilmiah peserta didik kelas IV MI Al-Huda Karangnongko Yogyakarta.

Beberapa faktor penyebab dalam penelitiandari pihak peneliti yang kurang dapat mengkondisikan peserta didik. Sehingga pada saat diskusi terdapat peserta didik yang ramai sendiri. Selain itu, dari tujuh sikap ilmiah menurut Harlen, peneliti hanya mengambil tiga sikap yaitu sikap ingin tahu, sikap senantiasa mendahulukan fakta, serta sikap berpikir terbuka dna kerja sama. Serta dari empat belas 
indikator, peneliti hanya mengambil enam indikator dari tiga sikap ilmiah yang diteliti. Sehingga kemungkinan, terdapat sikap ilmiah yang tidak diteliti namun muncul pada peserta didik. Sebab lain keterbatasan peneliti dalam melaksanakan metode group investigation yang kurang maksimal.

Pengembangan sikap ilmiah tidak bisa dilakukan hanya beberapa pertemuan. Namun, secara terus menerus dan berkelanjutan. Melalui peran guru untuk menggunakan metode pembelajaran ilmiah, serta memperlihatkan contoh sikap ilmiah penguatan positif pada sikap ilmiah peserta didik . Keterbatasan peneliti untuk menilai 28 peserta didik setiap kelas yang tidak maksimal menjadi salah satu kendala dalam penelitian.

Proses pembelajaran menggunakan metode group investigation kelas eksperimen selama dua pertemuan. Setiap kali pertemuan peneliti dibantu oleh satu orang pembantu peneliti. Satu pembantu peneliti bertugas untuk menilai sikap ilmiah saat proses pembelajaran menggunakan metode group investigation.

Menurut pembantu peneliti, terdapat beberapa langkah dalam penggunaan metode group investigation yang belum maksimal. Misalnya langkah peserta didik membuat laporan tidka dilakukan. serta memaparkan hasil investigasi terdapat beberapa kelompok yang tidak mendengarkan presentasi kelompok lain. Faktor tersebut dapat memperngaruhi sikap ilmiah. Karena metode yang digunakan juga belum maksimal.

\section{Kesimpulan}

Berdasarkan hasil hipotesis menggunakan analisis Mann Whitney maka diperoleh nilai Asymp. Sig. (2-tailed) =0,487 $>0,05$, maka $\mathrm{H}_{\mathrm{a}}$ ditolak dan $\mathrm{H}_{0}$ diterima. Hal ini berarti bahwa tidak terdapat perbedaan yang signifikan antara nilai rata-rata kelas eksperimen dan nilai rata-rata kelas kontrol. Jadi, dapat disimpulkan bahwa metode group investigation materi gaya tidak berpengaruh terhadap sikap ilmiah peserta didik di MI Al-Huda Karangnongko Yogyakarta. Hal ini disebabkan keterbatasan waktu penelitian sehingga metode group investigation kurang maksimal dan keterbatasan peneliti dalam mengkondisikan anak serta keterbatasan peneliti dalam menilai sikap ilmiah peserta didik berjumlah 28 setiap kelas.

\section{Daftar Pustaka}

Bundu, Patta. Penilaian Keterampilan Proses Dan Sikap Ilmiah Dalam Pembelajaran Sains SD. Jakarta: Departemen Pendidikan Nasional, 2006.

Darmodjo, Hendro. Pendidikan IPA II. Jakarta: Depdiknas, 1991.

E Slavin, Robert. Cooperative Learning. Bandung: Nusa Media, 2008.

Herabudin. Ilmu Alamiah Dasar. Bandung: Pustaka Setia, 2013.

Nurhadi, Yasin. B, and Senduk A.G, Pembelajaran Kontekstual (Contextual Teaching and Learning/ CTL) Dan Penerapaannya Dalam KBK. Malang: Universitas Negeri Malang, 2004.

Samatowa, Usman. Bagaimana Membelajaran

IPA Di Sekolah Dasar. Jakarta: Depdiknas, 2006.

Shoimin, Aris. 68 Model Pembelajaran Inovatif Dalam Kurikulum 2013. Rembang: ArRuzz Media, 2014.

Sugiyono. Metode Penelitian Kuantitatif, Kualitatif, Dan R \& D. Bandung: Alfabeta, 2016.

Syah, Muhibbin. Psikologi Pendidikan Dengan Pendekatan Baru. Bandung: Remaja Rosdakarya, 2014.

Winaputra, Udin S. Model Pembelajaran Inovatif. Jakarta: Universitas Terbuka, 2011. 